\title{
Pengaruh Pemberian Reward Stiker Bintang Terhadap Percaya Diri Anak Kelompok B di TK Thoriqussalam Sidoarjo
}

\author{
Zia Anggraeni Munawaroh ${ }^{1}$
}

Abstract: This research is motivated by the confidence of children in Thoriqussalam kindergarten who have not developed well. This is evidenced by the results of the pretest which shows 11 out of 15 children have not developed their confidence. This study aims to determine the level of confidence of group B children before and after being given treatment in the form of a star sticker reward and to determine the effect of the star sticker reward on the confidence of group $B$ children in TK Thoriqussalam Sidoarjo. The method used in this study is a quantitative research method with an experimental research model. The form of experiment used is Quasi Experimental with Non Equivalent Control Group Design. From the design of this study there were experimental groups that received treatment and a control group that did not get treatment. The assessment results obtained are based on the pretest and posttest of the experimental group and the control group. The results of this study are as follows: 1) The initial condition of the child's confidence before giving a reward sticker has not yet developed in the experimental group or the control group, this is evidenced by the results of the pretest that 11 of the 15 children in the experimental group received a value of 1 which means that it has not yet developed and 10 out of 15 children the control group received a score of 1 which means that it had not yet developed. 2) The final condition of a child's confidence after giving a star sticker reward is very different from the pretest in the experimental group and the control group, this is evidenced by the results of the posttest in the experimental group that 11 out of 15 children get a value of 4 which means that it develops very well. 3) Giving a star sticker reward influences the confidence of the Thoriqussalam kindergarten $B$ children in Sidoarjo, this is evidenced by Uhitung $=4$ and Utabel $=64$ on the condition of comparison that Uhitung <Utabel then reject $\mathrm{HO}$ and $\mathrm{Ha}$ are accepted.

Keywords : Confidence, Star Sticker Reward

Abstrak: Penelitian ini dilatarbelakangi oleh percaya diri anak di TK Thoriqussalam yang belum berkembang dengan baik. Hal ini dibuktikan dengan hasil pretest yang menunjukkan 11 dari 15 percaya diri anak belum berkembang. Penelitian ini bertujuan untuk mengetahui tingkat percaya diri anak kelompok B sebelum dan sesudah diberikan perlakuan berupa reward stiker bintang dan untuk mengetahui pengaruh dari reward stiker bintang terhadap percaya diri anak kelompok B di TK Thoriqussalam Sidoarjo. Metode yang digunakan dalam penelitian ini adalah metode penelitian kuantitatif dengan model penelitian eksperimen. Bentuk eksperimen yang digunakan adalah Quasi Experimental dengan desain Non Equivalent Control Group Design. Dari desain tersebut penelitian ini terdapat kelompok eksperimen yang mendapatkan perlakuan dan 
kelompok kontrol yang tidak mendapatkan perlakuan. Hasil penilaian yang diperoleh berdasarkan pretest dan posttest kelompok eksperimen dan kelompok kontrol. Hasil penelitian ini adalah sebagai berikut: 1) Kondisi awal percaya diri anak sebelum pemberian reward stiker bintang belum berkembang pada kelompok eksperimen maupun kelompok kontrol, hal ini dibuktikan dengan hasil pretest bahwa 11 dari 15 anak kelompok eksperimen memperoleh nilai 1 yang artinya belum berkembang dan 10 dari 15 anak kelompok kontrol memperoleh nilai 1 yang artinya belum berkembang. 2) Kondisi akhir percaya diri anak sesudah pemberian reward stiker bintang sangat berbeda dengan saat pretest pada kelompok eksperimen maupun kelompok kontrol, hal ini dibuktikan dengan hasil posttest pada kelompok eksperimen bahwa 11 dari 15 anak memperoleh nilai 4 yang artinya berkembang sangat baik. 3) Pemberian reward stiker bintang berpengaruh terhadap percaya diri anak kelompok B TK Thoriqussalam Sidoarjo, hal ini dibuktikan dengan Uhitung $=4$ dan Utabel $=64$ dengan syarat perbandingan bahwa Uhitung < Utabel maka tolak H0 dan Ha diterima.

Kata Kunci: Percaya Diri, Reward Stiker Bintang

\section{PENDAHULUAN}

Percaya diri merupakan aspek perkembangan sosial emosional anak yang perlu dikembangkan sejak dini. Perkembangan emosi anak dipengaruhi dari pemenuhan kebutuhan dasar anak yakni kebutuhan akan adanya percaya diri yang dimiliki oleh anak (Wiyani, 2014: 24). Percaya diri memiliki peran penting dalam pertumbuhan dan perkembangan anak. Dengan percaya diri anak akan siap menerima tantangan yang sedang dihadapi karena percaya diri merupakan unsur penting dalam menghadapi rintangan dan tantangan kehidupan di masa yang akan datang (Jayadianti, 2014: 30).

Percaya diri perlu dipelajari dengan mengacu pada indikator yang ingin dicapai.Namun kenyataannya bahwa percaya diri anak kelompok B belum berkembang dengan baik pada indikator berani tampil di depan umum.Percaya diri anak kelompok B yang belum berkembang dengan baik tersebut terlihat ketika proses pembelajaran bahwa anak masih malu dan kurang berani ketika diminta guru untuk maju bernyanyi maupun bercerita di depan kelas. Ketika diminta guru untuk maju ke depan kelas anak kelompok B malah menunjuk teman yang lain dan kurang berani untuk menampilkan dan menunjukkan kemampuan diri. Sehingga proses pembelajaran bernyanyi dan bercerita di depan kelas belum maksimal dilaksanakan (Observasi, 2018).

Faktor penyebab percaya diri anak kelompok B yang belum berkembang dengan baik pada indikator berani tampil di depan umum karena anak minder dan takut ditertawakan oleh teman-temannya apabila melakukan kesalahan. Anak juga merasa bahwa bernyanyi dan bercerita bukan keahliannya sehingga anak sering mengatakan tidak bisa sebelum mencoba. Selain itu, penggunaan motivasi masih jarang digunakan terutama dalam pemberian reward berupa penghargaan sehingga kurang memperkuat percaya diri anak dan percaya diri anak menjadi belum berkembang (NN, 2018).

Mengingat bahwa percaya diri anak sangat penting untuk dikembangkan sejak dini, maka peneliti memfasilitasi perkembangan percaya diri anak dengan pemberian reward 
berupa stiker bintang. Reward merupakan bentuk penghargaan yang dapat diberikan berupa senyuman, tepuk tangan atau yang lainnya. Reward memberikan fungsi yakni memiliki nilai mendidik, memberikan motivasi agar anak mengulangi atau mempertahankan perilaku tersebut agar diterima oleh orang lain dan memperkuat perilaku anak agar diterima orang lain (Hurlock, 1978: 90).

Stiker bintang merupakan bentuk penghargaan yang dapat ditempel dan disenangi oleh anak.Pemberian reward stiker bintang dapat memotivasi anak untuk mengembangkan sikap percaya diri. Dengan adanya stiker bintang dapat melihat semangat anak dalam mendapatkan stiker bintang yang lucu.Stiker bintang memotivasi anak untuk berhasil dalam mengulang dan mempertahankan sikap percaya diri (Rahayu, 2013: 3).

Rumusan masalah bagaimana tingkat percaya diri anak kelompok B di TK Thoriqussalam Sidoarjo sebelum pemberian reward stiker bintang? bagaimana tingkat percaya diri anak kelompok B di TK Thoriqussalam Sidoarjo sesudah pemberian reward stiker bintang? dan bagaimana pengaruh pemberian reward stiker bintang terhadap percaya diri anak kelompok B di TK Thoriqussalam Sidoarjo? Tujuan masalah untuk mengetahui tingkat percaya diri anak kelompok B di TK Thoriqussalam Sidoarjo sebelum pemberian reward stiker bintang, untuk mengetahui tingkat percaya diri anak kelompok B di TK Thoriqussalam Sidoarjo sesudah pemberian reward stiker bintang dan untuk untuk mengetahui pengaruh pemberian reward stiker bintang terhadap percaya diri anak kelompok B di TK Thoriqussalam Sidoarjo.

Jayadianti menjelaskan bahwa percaya diri adalah keberanian dalam melakukan sesuatu yang terbaik atausesuatu yang positif yang menjadikan anak siap untuk menghadapi segala sesuatu di masa yang akan datang (Jayadianti, 2014: 29). Percaya diri juga memiliki arti yaitu keyakinan terhadap kemampuan diri tampil di depan umum. Dalam hal ini bahwa anak yang percaya diri memiliki ciri-ciri yaitu percaya dengan kemampuan diri, tidak mudah bergantung pada orang lain, pengendalian diri yang baik dan memiliki keberanian bertindak (Fatimah, 2006: 149). Percaya diri dapat dikembangkan dengan beberapa cara yaitu memberikan reward, mendorong anak untuk melakukan hal baru, menghindari komentar yang negatif dan melabel yang negatif (Jayadianti, 2014: 30-31).

Pemilihan reward berupa stiker bintang dikarenakan anak senang dan tertarik dengan reward berupa stiker bintang yang mudah ditempel dimana saja. Selain itu reward dijadikan sebagai proses dalam pengubahan tingkah laku (Purwanta, 2012: 24). Dalam pemberian reward stiker bintang harus memperhatikan beberapa hal yaitu reward harus diberikan sesuai keadaan, reward disertai alasan dan reward diberikan secara hemat (Purwanto, 2011: 148).

\section{METODE}

Penelitian ini menggunakan pendekatankuantitatif dengan jenis eksperimen quasi experimental designdan bentuk desain non equivalent control group design. Penelitian 
eksperimen dipilih untuk membuktikan adanya pengaruh pemberian reward stiker bintang terhadap percaya diri anak yang mana penelitian eksperimen bertujuan untuk menemukan hubungan, pengaruh atau perbedaan salah satu variabel atau lebih variabel (Bungin, 2006: 49). Sedangkan desain ini dipilih untuk membandingkan antara kelompok eksperimen dan kelompok kontrol yang mana bahwa non equivalent control group design merupakan penelitian yang membandingkan kondisi kelompok eksperimen dan kelompok kontrol sebelum dan sesudah diberi perlakuan (Erwan Agus Purwanto \& Sulistyastuti, 2007: 90). Dalam hal ini bahwa kelompok eksperimen mendapatkan perlakuan dan kelompok kontrol tidak mendapatkan perlakuan. Kelompok eksperimen dan kelompok kontrol dibandingkan dari hasil pretest dan posttest.

Populasi dalam penelitian ini adalah anak kelompok B di TK Thoriqussalam yang berjumlah 67 anak. Sedangkan sampel dalam penelitian ini berjumlah 30 anak terdiri dari kelas B2 sebagai kelompok eksperimen berjumlah 15 anak dan kelas B4 sebagai kelompok kontrol berjumlah 15 anak. Sehingga teknik sampling yang digunakan ialahsampel non probability sampling dengan jenis teknik purposive sampling. Teknik purposive sampling merupakan teknik pengambilan sampel berdasarkan pertimbangan tertentu (Sugiyono, 2007: 85). Teknik sampling ini dipilih karena anak kelas B2 memiliki percaya diri yang belum berkembang dan jumlah anak antara kelas B2 dan B4 sama yaitu 15 anak.

Variabel penelitian menurut Sugiyono adalah penilaian dari orang lain untuk dipelajari dan untuk menarik kesimpulan (Siregar, 2014: 38). Variabel dalam penelitian ini ada dua yaitu variabel bebas dan variabel terikat yang mana variabel bebas ialah variabel yang mempengaruhi yaitu reward stiker bintang sedangkan variabel terikat ialah variabel yang dipengaruhi yaitu percaya diri anak.

Untuk memperoleh data dalam penelitian,peneliti menggunakan beberapa teknik untuk membantu dalam memperoleh data penelitian. Adapun data penelitian tersebut antara lain observasi, wawancaradan dokumentasi. Teknik observasi yang digunakan berupa teknik observasi non partisipan yakni peneliti hanya fokus pada hasil dari sebelum perlakuan dan sesudah perlakuan pemberian reward stiker bintang yang mana bahwa teknik observasi non partisipan merupakan teknik observasi tanpa terlibat secara langsung dalam kegiatan yang dilaksanakan (Sugiyono, 2007: 145). Selain observasi, peneliti juga melakukan wawancara dengan teknik wawancara terstruktur yang mana peneliti membuat dan menyiapkan pertanyaan sebagai pedoman wawancara karena wawancara terstruktur merupakan teknik mencari informasi dengan pedoman wawancara (Sugiyono, 2007: 140). Peneliti mengadakan wawancara dengan guru kelas TK B yang berinisial NN.Dokumentasi yang dilakukan pada penelitian ini dengan mencari data berupa RPPH, surat izin penelitian, surat keterangan melakukan penelitian, surat keterangan validitas dan uji reliabilitas, lembar validasi RPPH dan foto kegiatan.

Penelitian ini menggunakan instrumen berupa lembar observasi untuk mengukur dan menilai percaya diri anak sebelum dan sesudah diberikan perlakuan (treatment). Setelah instrumen penelitian dibuat kemudian dilakukan pengujian instrumen agar dapat dipertanggung jawabkan kebenarannya yang dinamakan validitas instrumen. Arikuntomenjelaskan bahwa validitas adalah ukuran dalam menunjukkan tingkat kevalidan suatu instrumen (Arikunto, 2006: 168). Dalam penelitian ini menggunakan validitas konstruk yaitu expert judgment yang mana instrumen penelitian kemudian divaliditaskan dengan cara konsultasi dengan para ahli.

Reliabel menurut Arikunto adalah kepercayaan terhadap instrumen sebagai alat pengumpul data yang sudah baik (Arikunto, 2006: 178). Jadi apabila instrumen penelitian 
tersebut sudah reliabel atau dapat dipercaya maka akan menghasilkan data yang reliabel atau dapat dipercaya. Penelitian ini menggunakan reliabilitas pengamatan dengan bantuan pengamat I dan pengamat II. Peneliti menentukan tempat uji reliabilitas yang memiliki topik permasalahan yang sama dengan subjek yang akan diteliti. Kemudian pengamat I dan pengamat II melakukan observasi dengan mengisi format penilaian secara bersamasama. Hasil penilaian tersebut kemudian diuji dengan rumus H.J.X Fernandes (Arikunto, 2006: 201).

$$
\mathrm{KK}=\frac{2 \mathrm{~S}}{\mathrm{~N} 1+\mathrm{N} 2}
$$

Keterangan:

$\mathrm{KK} \quad=$ Koefisien Kesepakatan

$\mathrm{S} \quad=$ sepakat, jumlah kode yang sama untuk objek yang sama

$\mathrm{N}_{1} \quad$ = jumlah kode yang dibuat oleh pengamat I

$\mathrm{N}_{2} \quad$ = jumlah kode yang dibuat oleh pengamat II

Selanjutnya memasukkan data kode pengamatan ke dalam tabel kontingensi. Tabel kontingensi dimaksudkan untuk memudahkan dalam menyamakan nilai kesepakatan antara pengamat I dan pengamat II.

Analisa data menurut Siregar adalah kegiatan menganalisis data yang meliputi pengolahan dan pengujian data, melakukan perhitungan untuk mendeskripsikan data serta melakukan pengujian hipotesis dengan uji statistik (Siregar, 2014: 86). Dalam penelitian ini menggunakan analisa data dengan rumus Mann Whitney U Test yang mana bahwa rumus ini untuk menguji hipotesis dengan jenis data ordinal dan sampel yang independen (Sugiyono, 2007: 151).

\section{HASIL PENELITIAN DAN ANALISIS}

Berdasarkan hasil observasi saat pretest pada kegiatan bernyanyi maupun bercerita di kelompok eksperimen dan kelompok kontrol anak masih terlihat malu dan ragu ketika bernyanyi dan bercerita di depan kelas. Hal tersebut karena anak belum menunjukkan keberanian bernyanyi dan bercerita di depan kelas dengan baik.

Hasil pretest pada kelompok eksperimen saat kegiatan bernyanyi di depan kelas menunjukkan bahwa anak yang memperoleh nilai 3 ada 2 anak yang artinya percaya diri anak berkembang sesuai harapan (BSH), anak yang memperoleh nilai 2 ada 2 anak yang artinya percaya diri anak mulai berkembang (MB)dan anak yang memperoleh nilai 1 ada 11 anak yang artinyapercaya diri anak belum berkembang (BB). Sedangkan pada kegiatan bercerita di depan kelas percaya diri anak belum berkembang (BB) ditunjukkan dengan pemerolehan nilai 1 ada 15 anak.

Hasil pretest pada kelompok kontrol saat kegiatan bernyanyi di depan kelas menunjukkan bahwa anak yang memperoleh nilai 3 ada 5 anak yang artinya percaya diri anak berkembang sesuai harapan (BSH) dan anak yang memperoleh nilai 1 ada 10 anak yang artinya percaya diri anak belum berkembang (BB). Sedangkan pada kegiatan bercerita di depan kelas anak yang memperoleh nilai 2 ada 2 anak yang artinya percaya diri anak mulai berkembang (MB) dan anak yang memperoleh nilai 1 ada 13 anak yang artinya percaya diri anak belum berkembang (BB).

Berdasarkan hasil observasi saat posttest pada kelompok eksperimen menunjukkan bahwa anak telah menunjukkan perkembangan percaya diri yang sangat baik. Anak senang, antusias dan semangat bernyanyi dan bercerita di depan kelas. 
Hasil posttest pada kelompok eksperimen saat kegiatan bernyanyi di depan kelas menunjukkan bahwa anak yang memperoleh nilai 4 ada 13 anak yang artinya percaya diri anak berkembang dengan baik (BSB) dan anak yang memperoleh nilai 3 ada 2 anak yang artinya percaya diri anak berkembang sesuai harapan (BSH). Sedangkan pada kegiatan bercerita di depan kelas anak yang memperoleh nilai 4 ada 11 anak yang artinya percaya diri anak berkembang sangat baik (BSB) dan anak yang memperoleh nilai 3 ada 4 anak yang artinya percaya diri anak berkembang sesuai harapan (BSH).

Hasil posttest pada kelompok kontrol saat kegiatan bernyanyi di depan kelas menunjukkan bahwa anak yang memperoleh nilai 4 ada 7 anak yang artinya percaya diri anak berkembang sangat baik (BSB), anak yang memperoleh nilai 3 ada 1 anak yang artinya percaya diri anak berkembang sesuai harapan (BSH) dan anak yang memperoleh nilai 2 ada 7 anak yang artinya percaya diri anak mulai berkembang (MB). Sedangkan pada kegiatan bercerita di depan kelas anak yang memperoleh nilai 3 ada 3 anak yang artinya percaya diri anak berkembang sesuai harapan (BSH) dan anak yang memperoleh nilai 2 ada 12 anak yang artinya percaya diri anak mulai berkembang (MB).

Berdasarkan hasil analisis data menggunakan rumus mann whitney $u$ test, diketahui bahwa $U_{\text {hitung }}=4$ dan $\mathrm{U}_{\text {tabel }}=64$ maka dalam membandingkan antara $U_{\text {hitung }}$ dan

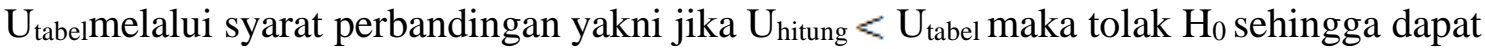
dituliskan $4<64$ yang berarti bahwa $\mathrm{H}_{0}$ ditolak dan $\mathrm{H}_{\mathrm{a}}$ diterima. Dapat disimpulkan bahwa ada pengaruh pemberian reward stiker bintang terhadap percaya diri anak kelompok B di TK Thoriqussalam Sidoarjo.

\section{PEMBAHASAN}

Penelitian ini dilakukan dengan pengukuran awal (pretest), pemberian perlakuan (treatment) dan pengukuran akhir (posttest). Pengukuran awal yang dilakukan untuk mengetahui kondisi awal percaya diri anak kelompok B. Kegiatan yang dilakukan pada saat pengukuran awal adalah kegiatan bernyanyi dan bercerita di depan kelas. Hasil dari pengukuran awal menunjukkan bahwa pada kelompok eksperimen anak-anak masih ragu dan malu untuk bernyanyi dan bercerita di depan kelas. Berdasarkan data yang diperoleh pada kelompok eksperimen menunjukkan bahwa dari 15 anak yang memperoleh nilai 1 ada 11 anak yang artinya percaya diri anak belum berkembang (BB) pada kegiatan bernyanyi di depan kelas. Pada kegiatan bercerita di depan kelas 15 anak memperoleh nilai 1 yang artinya percaya diri anak belum berkembang (BB). Sedangkan data yang diperoleh pada kelas kontrol menunjukkan bahwa dari 15 anak yang memperoleh nilai 1 ada 10 anak yang artinya percaya diri anak belum berkembang (BB) pada kegiatan bernyanyi di depan kelas. Pada kegiatan bercerita di depan kelas 13 anak memperoleh nilai 1 yang artinya percaya diri anak belum berkembang (BB). Dengan demikian data menunjukkan bahwa percaya diri anak sebelum diberi perlakuan termasuk dalam kategori belum berkembang (BB).

Langkah selanjutnya pemberian treatment dengan pemberian reward stiker bintang pada kelompok eksperimen dan tidak memberikan treatment pada kelompok kontrol karena sebagai pembanding. Reward yang diberikan berupa stiker bintang dengan gambar tertawa dan gambar tersenyum.

Setelah dilakukan treatment dilanjutkan dengan pengukuran akhir (posttest) untuk mengukur dan membandingkan antara kelompok eksperimen dan kelompok kontrol. 
Hasil dari pengukuran akhir menunjukkan bahwa pada kelompok eksperimen anak antusias, senang dan berani untuk bernyanyi dan bercerita di depan kelas. Berdasarkan data yang diperoleh pada kelompok eksperimen bahwa dari 15 anak yang memperoleh nilai 4 ada 13 anak yang berarti percaya diri anak berkembang sangat baik (BSB) pada kegiatan bernyanyi di depan kelas dan memperoleh nilai 4 ada 11 anak yang berarti percaya diri anak berkembang sangat baik (BSB) pada kegiatan bercerita di depan kelas. Hal itu menunjukkan bahwa percaya diri anak pada kegiatan bernyanyi dan bercerita berkembang sangat baik (BSB). Dengan demikian data menunjukkan bahwa percaya diri anak sesudah diberi perlakuan pada kelompok eksperimen termasuk dalam kategori berkembang sangat baik (BSB). Sedangkan data yang diperoleh pada kelompok kontrol menunjukkan bahwa dari 15 anak ada 7 anak yang memperoleh nilai 4 yang artinya percaya diri anak berkembang sangat baik (BSB) pada kegiatan bernyanyi di depan kelas dan pada kegiatan bercerita di depan kelas tidak ada yang memperoleh nilai 4 melainkan ada 12 anak yang memperoleh nilai 2 yang artinya percaya diri anak mulai berkembang (MB). Dengan demikian dapat dikatakan bahwa percaya diri anak pada kelompok kontrol mulai berkembang (MB).

Setelah dilakukan pretest dan posttest kemudian dilakukan perhitungan analisis data dan didapatkan $\mathrm{U}_{\text {hitung }}=4, \mathrm{U}_{\text {tabel }}=64$. Dengan memenuhi syarat perbandingan bahwa $\mathrm{U}_{\text {hitung }}<\mathrm{U}_{\text {tabel }}$ maka dapat dituliskan $4<64$ sehingga $\mathrm{H}_{0}$ ditolak dan $\mathrm{H}_{\mathrm{a}}$ diterima.

Berdasarkan perbandingan data dan analisis data dapat dikatakan bahwa pemberian reward stiker bintang berpengaruh pada percaya diri anak kelompok B di TK Thoriqussalam Sidoarjo.

Percaya diri anak mengalami perkembangan saat sebelum dan sesudah perlakuan pada kelompok eksperimen.Percaya diri anak mengalami perkembangan karena pengaruh pemberian reward stiker bintang. Hal tersebut sesuai dengan yang dikatakan Severe bahwa pemberian stiker bintang dapat mengembangkan percaya diri anak (Rahayu, 2013: 3). Dapat dikatakan bahwa reward stiker bintang dengan percaya diri memiliki implikasi yang berasal dari tujuan yang ingin dicapai. Reward dapat mengubah perilaku anak termasuk sikap percaya diri anak. Percaya diri merupakan keyakinan dalam menampilkan diri di depan orang lain. Ardy menjelaskan bahwa percaya diri erat kaitannya dengan keyakinan dan sikap yang ditampilkan seseorang di depan orang lainnya (Wiyani, 2014: 124). Percaya diri anak juga dipengaruhi oleh anak yang termotivasi untuk mengembangkan percaya diri dan lingkungan sekolah yang memberikan motivasi berupa reward stiker bintang serta pengakuan oleh guru sehingga memberikan kebanggaan pada diri anak. Pengaruh tersebut mendorong dan memotivasi anak untuk mengembangkan sikap percaya diri.

\section{SIMPULAN DAN SARAN \\ Simpulan}

Berdasarkan hasil penelitian tentang pengaruh pemberian reward stiker bintang terhadap percaya diri anak kelompok B dapat disimpulkan beberapa hal sebagai berikut: 1) Percaya diri anak kelompok $B$ dapat dikatakan belum berkembang pada saat pretest. Hal ini terbukti dari hasil analisis data pretest menunjukkan bahwa pada kelompok eksperimen terdapat 11 anak yang memperoleh nilai 1 pada kegiatan bernyanyi dan pada kegiatan bercerita terdapat 15 anak yang memperoleh nilai 1 . Pada kelompok kontrol terdapat 10 anak yang memperoleh nilai 1 pada kegiatan bernyanyi sedangkan pada 
kegiatan bercerita terdapat 13 anak yang memperoleh nilai 1. Sehingga percaya diri anak kelompok B dikatakan belum berkembang (BB).

2) Percaya diri anak kelompok $B$ sesudah diberi perlakuan atau treatment yakni pemberian reward stiker bintang mengalami perubahan yang signifikan. Hal ini terbukti dari hasil analisis dataposttest pada kelompok eksperimen bahwa dari 15 anak yang memperoleh nilai 4 ada 13 anak pada kegiatan bernyanyi dan yang memperoleh nilai 4 ada 11 anak pada kegiatan bercerita di depan kelas. Hal itu menunjukkan bahwa percaya diri anak pada kelompok eksperimen berkembang sangat baik (BSB). Sedangkan dari hasil analisis data posttest pada kelompok kontrol yakni kelas yang tidak mendapat perlakuan menunjukkan bahwa dari 15 anak hanya 7 anak yang memperoleh nilai 4 pada kegiatan bernyanyi di depan kelas dan tidak ada yang memperoleh nilai 4 pada kegiatan bercerita di depan kelas. Dengan demikian dapat dikatakan bahwa percaya diri anak pada kelompok kontrol mulai berkembang (MB). 3) Berdasarkan hasil analisis data pretest dan posttest pada kelompok eksperimen dan kelompok kontrol yang kemudian dibandingkan bahwa $\mathrm{U}_{\text {hitung }}<\mathrm{U}_{\text {tabel }}$ maka dapat dituliskan $4<64$ sehingga $\mathrm{H}_{0}$ ditolak dan $\mathrm{H}_{\mathrm{a}}$ diterima.

Dengan demikian dapat disimpulkan bahwa ada pengaruh pemberian reward stiker bintang terhadap percaya diri anak kelompok B di TK Thoriqussalam Sidoarjo.

\section{Saran}

Setelah melakukan penelitian tentang pengaruh pemberian reward stiker bintang terhadap percaya diri anak kelompok B di TK Thoriqussalam Sidoarjo, ada beberapa saran yang dapat diberikan oleh peneliti sebagai berikut: 1) Untuk mengembangkan sikap percaya diri anak tidak hanya dilakukan pada kegiatan inti saja melainkan dapat dilakukan pada kegiatan lain seperti kegiatan awal dan kegiatan akhir pembelajaran. 2) Kegiatan yang dilakukan untuk mengembangkan percaya diri anak dapat dilakukan tidak hanya pada kegiatan bernyanyi dan bercerita di depan kelas melainkan dapat dilakukan pada kegiatan bermain peran ataupun kegiatan lainnya. 3) Bentuk gambar stiker bintang yang diberikan bisa bermacam-macam tidak hanya gambar muka tertawa dan gambar muka tersenyum serta stiker bintang yang diberikan bisa berwarna-warni tidak hanya berwarna kuning. 4) Penelitian ini dapat dijadikan referensi penelitian bagi peneliti selanjutnya dengan melengkapi kekurangan penelitian ini.

\section{AKNOWLEDGMENT}

Peneleitian ini di dukung oleh PG TK Islam Sabilillah Sidoarjo.

\section{DAFTAR RUJUKAN}

Arikunto, S. (2006). Prosedur Penelitian Suatu Pendekatan Praktik. Jakarta: Rineka Cipta.

Bungin, M. B. (2006). Metodologi Penelitian Kuantitatif. Jakarta: Kencana.

Erwan Agus Purwanto, \& Sulistyastuti, D. R. (2007). Metode Penelitian Kuantitatif. Yogyakarta: Gava Media.

Fatimah, E. (2006). PsikologiPerkembangan (Perkembangan Peserta Didik). Bandung: Pustaka Setia.

Hurlock, E. B. (1978). Perkembangan anak jilid 1. Jakarta: Erlangga. 
Jayadianti, H. (2014). Menumbuhkembangkan Intrapersonal Anak (Usia 0-6 tahun). Tangerang: Tirtamedia.

NN. (2018). Wawancara. Sidoarjo.

Observasi. (2018). Sidoarjo.

Purwanta, E. (2012). Modifikasi Perilaku. Yogyakarta: Pustaka Pelajar.

Purwanto, N. (2011). Ilmu Pendidikan Teoritis dan Praktis. Bandung: Remaja Rosdakarya.

Rahayu, D. P. (2013). Pengaruh Penerapan Reward Terhadap Percaya Diri Anak Kelompok B di TK Nglanduk 01 Madiun, Jurnal PAUD Teratai. Jurnal PAUD Teratai.

Siregar, S. (2014). Metode Penelitian Kuantitatif. Jakarta: Kencana.

Sugiyono. (2007). Metode Penelitian Kuantitatif Kualitatif dan R\&D. Bandung: Alfabeta.

Wiyani, N. A. (2014). Mengelola Mengembangkan Kecerdasan Sosial \& Emosi Anak Usia Dini. Yogyakarta: Ar-Ruzz Media.

\section{AUTHOR}

Zia Anggraeni Munawaroh, merupakan guru PG TK Islam Sabilillah Sidoarjo 